\title{
TRANSNATIONAL ORGANISED CRIME IN INDONESIA - THE NEED FOR INTERNATIONAL COOPERATION
}

\author{
James N Mitchell ${ }^{1}$
}

\begin{abstract}
Along with technological development as well as borderless phenomenon in the era of globalization, transnational organised crime emerged. The rapid rise of transnational organised crime in the South East Asian region over recent years has prompted action by nations acting both domestically through legislation and policies, as well as internationally through bilateral and multilateral cooperation. ${ }^{2}$

East Asia plays host to a vast array of transnational crimes ${ }^{3}$, however, the ones which will be specifically addressed within this essay are human trafficking, terrorism, wildlife trafficking and piracy. Each issue will be examined individually, with a preliminary outline of the crime's nature, followed by an analysis of specific domestic and international approaches towards combatting it. It will be argued that the effective control of transnational organised crime requires more than individual States working individually to protect their own interests. International cooperation between States that involves coherent and consistent strategies tailored to the nature of the crime is essential if transnational organised crime is to be effectively counteracted within East Asia.
\end{abstract}

Keywords: Transnational Organized Crime, South East Asia, Cooperation

\section{INTRODUCTION}

Transnational organised crime is an ever-expanding global problem with far-reaching impacts in all corners of the world. ${ }^{4}$ For the purposes of this essay, 'transnational organised crime' is

1 Student of Law School, Faculty og Law, Humanity and Arts, University of Wollongong

2 Muhammad Mustofa, 'Bilateral Cooperation Between Indonesia and Malaysia in Combating Transnational Crime' (2008) 5 Indonesian Journal of International Law 525, 526.

3 Transnational Organised Crime in East Asia and the Pacific, iii.

4 Michael Wesley, 'Transnational Crime and Security Threats in Asia' (Report, Australian defined broadly to refer to the 'behaviour of ongoing organizations that involves two or more nations, with such behaviour being defined as criminal by at least one of these nations'.5 This definition is sufficiently broad and

\footnotetext{
Agency for International Development, December 2007) 1.

${ }^{5}$ Peng Wang and Jingyi Wang, 'Transnational Crime: Its Containment through International Cooperation' (2009) 5 Asian Social Science 25, 26, quoting J. Martin and A. Romano, Multinational Crime-Terrorism, Espionage, Drug \& Arms Trafficking (Sage Publishing, 1999) 15.
} 
accounts for the possibility of jurisdictional discrepancies in the criminalisation of certain activities.

The rapid growth of transnational organised crime in South East Asia has been aided by the phenomenon of globalisation, the increased interconnectedness of the world's sovereign states. ${ }^{6}$ Globalisation has had hugely beneficial effects for society, improving the global economy, propelling the 'information revolution', and allowing for increased international inter-personal connectivity on a scale previously unheard of. ${ }^{7}$

However, despite the numerous benefits globalisation has produced, it has also allowed criminals to seamlessly coordinate and carry out their illegal activities across national borders. ${ }^{8}$ The rapid growth of transnational organised crime cannot be understated, worldwide it was estimated in 2009 to generate over USD $\$ 870$ billion annually. ${ }^{9}$ Within East Asia and the Pacific region alone, the

\footnotetext{
${ }^{6}$ Wesley, above $\mathrm{n} 1,1$.

${ }^{7}$ Wang and Wang, above n 2, 2.

${ }^{8}$ Wesley, above $\mathrm{n} 1,2$.

${ }^{9}$ United Nations Office on Drugs and Crime, Estimating Illicit Financial Flows Resulting from Drug Trafficking and other Transnational Organized Crimes, (October 2011) 7.

10 United Nations Office on Drugs and Crime, Transnational Organised Crime in East Asia and the Pacific - A Threat Assessment, (April 2013) 1
}

growth of transnational organised crime has been so rapid in recent years that as of 2014 it has been conservatively estimated to generate over USD \$90 billion annually, an amount which gains even greater significance when compared to the gross domestic product (GDP) of many countries in the South East Asian region. ${ }^{10}$

The rapid rise of transnational organised crime in the South East Asian region over recent years has prompted action by nations acting both domestically through legislation and policies, as well as internationally through bilateral and multilateral cooperation. ${ }^{11}$ At a regional level, this is evidenced through the efforts of the Association of South East Asian Nations (ASEAN), which have created the ASEAN Political-Security Community Framework which aims to facilitate and strengthen political and security cooperation within member States. ${ }^{12}$

('Transnational Organised Crime in East Asia and the Pacific').

${ }^{11}$ Muhammad Mustofa, 'Bilateral Cooperation Between Indonesia and Malaysia in Combating Transnational Crime' (2008) 5 Indonesian Journal of International Law 525, 526.

${ }^{12}$ Adi Kusumaningrum, 'The ASEAN PoliticalSecurity Community: ASEAN Security Cooperation on Combatting Transnational Crimes' (2013) Indonesian Journal of International Law 89, 91. 
East Asia plays host to a vast array of transnational crimes, ${ }^{13}$ however, the ones which will be specifically addressed within this essay are human trafficking, terrorism, wildlife trafficking and piracy. Each issue will be examined individually, with a preliminary outline of the crime's nature, followed by an analysis of specific domestic and international approaches towards combatting it. It will be argued that the effective control of transnational organised crime requires more than individual States working individually to protect their own interests. International cooperation between States that involves coherent and consistent strategies tailored to the nature of the crime is essential if transnational organised crime is to be effectively counteracted within East Asia.

\section{RESULT AND DISCUSSION} Human Trafficking - Indonesia's Domestic And International Response

${ }^{13}$ Transnational Organised Crime in East Asia and the Pacific, iii.

14 Romli Atmasasmita, 'International Cooperation on Combating Human Trafficking Especially Women and Children: A View from Indonesia', (2004) 1 Indonesian Journal of International Law 673, 675.

${ }^{15}$ United Nations Office on Drugs and Crime, Global Report on Trafficking in Persons, (February 2009) 8 ('Global Report on Trafficking in Persons 2009').
Human trafficking is considered to be one of the largest crimes of the twentieth century ${ }^{14}$ and despite increased global action to combat it since 2000 it remains one of the most pervasive transnational crimes. ${ }^{15}$ 'Human trafficking' is an umbrella term used to describe the situation in which one person holds another in involuntary servitude. ${ }^{16}$ Although generating a precise figure of the amount of trafficking victims worldwide is complex and has not recently been possible with any certainty, ${ }^{17}$ in 2005 it was estimated that there were over 2.5 million individuals being exploited as victims of human trafficking, with annual profits from trafficking amounting to over USD \$31 billion. ${ }^{18}$ Human trafficking has detrimental impacts on almost all sectors of society; it harms the economy of both the country of origin and destination, victims often suffer endure serious traumatic conditions, causes breakdowns of social

16 U.S. Department of State, Trafficking in Persons Report (2011) <http://www.state.gov/j/tip/rls/tiprpt/ 2011/164220.htm>.

${ }^{17}$ United Nations Office on Drugs and Crime, Global Report on Trafficking in Persons, (2014) 16

18 Jeremy Hakem, Transnational Crime in the Developing World (Global Financial Integrity, 2011) 7-8. 
structure, and through corruption it erodes the capacity of the state to effectively protect its citizens. ${ }^{19}$

Indonesia is a major source country of trafficking victims involved in forced labour and sexual exploitation..$^{20}$ As a country, Indonesia's people are susceptible to becoming victims of human trafficking for many reasons that include poverty, a lack of available employment and education, unequal gender roles, ${ }^{21}$ and the fact that as of 2013 only 67\% of Indonesian children are registered with a birth certificate. $^{22}$

A further contributing factor to Indonesia's ongoing struggle with human trafficking is that it was not until the first decade of the $21^{\text {st }}$ century that the country developed a concerted national effort to combat human trafficking. Prior to this Indonesia did not have a law against all forms of

\footnotetext{
${ }^{19}$ Ibid 10 .

20 U.S. Department of State, Trafficking in Persons Report (2011) 191 <http://www.state.gov/j/tip/rls/tiprpt/ 2011/164232.htm>.

${ }^{21}$ United Nations Office on Drugs and Crime, UNODC Country Programme for Indonesia, 2012-2015 (2012)

$<$ https://www.unodc.org/documents/southeastas iaandpacific//indonesia/publication/ Country_Programme_Indonesia.pdf $>$.

22 United Nations Children's Fund, 'Every Child's Birth Right Inequities and Trends in
}

human trafficking and the only specific legislative provisions on trafficking related to women and children. ${ }^{23}$ Enforcement of the trafficking laws was also lax, with maximum sentences rarely imposed, widespread official corruption, and government action limited by funding and the difficulty of monitoring an area the size of the Indonesian archipelago. $^{24}$ This combination of factors made human trafficking effectively beyond the scope of Indonesia's control and along with international pressures, made it necessary for the nation to work towards the introduction of its first comprehensive anti-trafficking legislation. ${ }^{25}$

Since the turn of the century, Indonesia has made significant advancements in developing a stronger approach towards human trafficking. ${ }^{26}$ In 2002 the Indonesian National Plan of

Birth Registration’ (UNICEF, December 2013) 41.

${ }^{23}$ Global Report on Trafficking in Persons 2009, 170.

24 U.S. Department of State, Trafficking in Persons Report (2002) <http://www.state.gov/j/tip/rls/tiprpt/2002/ 10680.htm>

${ }^{25}$ Diana Betz, 'Human Trafficking in Southeast Asia: Causes and Policy Implications (Master’s Thesis, Naval Postgraduate School, Monterey, California, 2009) 64.

26 Nugroho Wisnumurti, 'Maritime Security Issues in Southeast Asia: An Indonesian 
Action for the Elimination of Trafficking in Women and Children was enacted, ${ }^{27}$ and in 2007 the Indonesian government introduced comprehensive antitrafficking legislation. ${ }^{28}$ This was Indonesia's first national legislation that defined human trafficking explicitly and expansively enough to cover all forms of trafficking into and out of Indonesia. Whilst there has been an increase in antitrafficking prosecutions and convictions since the enactment of this legislation, reports suggest that corruption, a lack of funding for anti-trafficking task forces, and unfamiliarity with the antitrafficking laws have all contributed to a less than optimal response to human trafficking within Indonesia. ${ }^{29}$

Indonesia's increased domestic efforts to combat human trafficking

Perspective' (2009) 6 Indonesian Journal of International Law 333, 342.

${ }^{27}$ Global Report on Trafficking in Persons 2009, 170.

${ }^{28}$ Law of the Republic of Indonesia Number 21 2007, Law on The Eradication of the Criminal Act of Trafficking in Persons.

29 U.S Department of State, Trafficking in Persons Report (2010) 177

<http://www.state.gov/documents/ organization/142979.pdf>.

30 United Nations Convention against Transnational Organised Crime, GA Res 55/25, UN GAUR, 55 ${ }^{\text {th }}$ sess, $62^{\text {nd }}$ plen mtg, Agenda Item 105, Supp No 49, UN Doc A/RES/55/25 (15 November 2000) iii.

${ }^{31}$ Ibid.

32 Ibid annex II ('Protocol to Prevent, Suppress and Punish Trafficking in Persons, Especially came about following increased international attention towards human trafficking and the worldwide recognition of it as a serious transnational organised crime. ${ }^{30} \mathrm{~A}$ united global effort to address human trafficking was crystallised in 2000 with the introduction of the United Nations Convention against Transnational Organised Crime (Palermo Convention) $^{31}$ and its associated Protocol to Prevent, Suppress and Punish Trafficking in Persons, Especially Women and Children (Trafficking Protocol). ${ }^{32}$ The Palermo Convention and the Trafficking Protocol were introduced with the aims of removing differences between state laws, setting a common standard to combat human trafficking and

Women and Children, Supplementing the United Nations Convention against Transnational Organised Crime'). The Protocol defines 'human trafficking' to mean 'the recruitment, transportation, transfer, harbouring or receipt of persons, by means of the threat or use of force or other forms of coercion, of abduction, of fraud, of deception, of the abuse of power or of a position of vulnerability or of the giving or receiving of payments or benefits to achieve the consent of a person having control over another person, for the purpose of exploitation. Exploitation shall include, at a minimum, the exploitation of the prostitution of others or other forms of sexual exploitation, forced labour or services, slavery or practices similar to slavery, servitude or the removal of organs. 
promoting cooperation between state parties to effectively achieve this. ${ }^{33}$

Indonesia became a signatory to both the Palermo Convention and the Trafficking Protocol on 12 December 2000, signifying their intent and willingness to adhere to and ratify both documents. ${ }^{34}$ However, it was not until 2009 that Indonesia ratified the Palermo Convention and the Trafficking Protocol, meaning that until this time the country was not considered bound to adhere to either document. ${ }^{35}$

It is evident that international focus has prompted Indonesia to work towards creating a stronger approach to address trafficking within the South East Asian region. Such international focus is epitomised by the publishing by the United States Department of State's Office to Monitor and Combat Trafficking in Persons of the 'Trafficking in Persons Report' (TIP Report). ${ }^{36}$ These reports have been

\footnotetext{
${ }^{33}$ Geoffrey Yussouf, 'Global Human Trafficking and the UN Convention against Transnational Organised Crime' (2008) 1 University College London Human Rights Review 173, 179.

34 Vienna Convention on the Law of Treaties, opened for signature 23 May 1969, 1115 UNTS 331 (entered into force 27 January 1980) arts 10, 18.

${ }^{35}$ Ibid arts 2(1)(b), 16.

${ }^{36}$ Rizal Sukma, 'The Securitization of Human Trafficking in Indonesia' (Working Paper, S.
}

published annually since 2001 and rank countries into one of three tiers depending on their government's level of compliance with the minimum standards for the elimination of trafficking outlined by the United States' anti-trafficking legislation. ${ }^{37}$

Indonesia was placed in tier 3 in the 2001 TIP Report alongside the South East Asian countries of Burma and Malaysia, signalling that the country did not comply with the minimum standards for the elimination of trafficking and was not making significant efforts to do so. ${ }^{38}$ Countries placed in tier 3 are at risk of sanctions from the United States in the form of restrictions on funding, especially relating to counteracting of human trafficking. ${ }^{39}$ Consequentially, in the following years Indonesia increased its efforts to combat human trafficking which were acknowledged by its upgrade to tier 2 of the TIP report in $2003^{40}$ where the country has remained

Rajaratnam School of International Studies, Singapore, 3 July 2008, 8.

${ }^{37}$ Ibid.

38 U.S. Department of State, Trafficking in Persons Report (2001) 87 < http://www.state.gov/documents/ organization/4107.pdf>.

${ }^{39}$ Sukma, above n 32, 19.

40 U.S. Department of State, Trafficking in Persons Report (2003) 82 http://www.state.gov/documents/ organization/21555.pdf. 
since. ${ }^{41}$ It may therefore be argued that Indonesia has strengthened its approach towards human trafficking as part of cooperation on an international scale with the United States. Were it not for this cooperation and the funding aid provided by the United States, it is probably that the Indonesian government would be unable to allocate sufficient resources to combat human trafficking.

Further, Indonesia has utilised international cooperation via bilateral and multilateral arrangements with other nations to address human trafficking. Bilateral Memorandums of Understanding have been introduced with Malaysia, ${ }^{42}$ Taiwan $^{43}$ and most recently the United Arab Emirates in $2015^{44}$ with the intent of preventing the trafficking of individuals out of Indonesia. Whilst these bilateral initiatives are an important component of

${ }^{41}$ See U.S. Department of State's Trafficking in Persons Reports from 2003-2015, which can be accessed $<$ http://www.state.gov/j/tip/rls/tiprpt/index.htm> 42 Memorandum of Understanding between Government of the Republic of Indonesia and the Government of Malaysia on the Recruitment and Placement of Indonesian Domestic Workers, signed 13 May 2006.

${ }^{43}$ Wendy Zeldin, Indonesia; Taiwan: Agreement to Combat Human Trafficking (October 5 2012)

Library of Congress

$<$ http://www.loc.gov/law/foreign-

news/article/indonesia-taiwan-agreement-tocombat-human-trafficking/>. addressing human trafficking, regional cooperative action is essential as there are many avenues through which people may be trafficked, and vast resources are required to enforce anti-trafficking laws. ${ }^{45}$

In recognition of the need for cohesive regional action to disrupt human trafficking throughout South East Asia, in 2002 the governments of Indonesia and Australia jointly convened the Bali Ministerial Conference on People Smuggling, Trafficking in Persons and Related Transnational Crime, now referred to as the Bali Process. ${ }^{46}$ The Bali Process aims to promote collaboration between all Member States in areas such as information sharing, cooperation between border security forces, strong national legislation and increasing opportunities for legal migration. ${ }^{47}$

\footnotetext{
${ }^{44}$ United Arab Emirates National Committee to Combat Human Trafficking, UAE, Indonesia to Sign MoU on Anti-Human Trafficking (13 September 2015) $<$ http://www.nccht.gov.ae/default.aspx?PageId= 66\&EventID=2>.

${ }^{45}$ Lindsey King, 'International Law and Human Trafficking’ (2009) Human Rights \& Human Welfare 88, 90 $<$ http://www.du.edu/korbel/hrhw/researchdigest /trafficking/Trafficking.pdf $>$.

${ }^{46}$ Wisnumurti, above n 22, 344

${ }^{47}$ About the Bali Process, The Bali Process on People Smuggling, Trafficking in Persons and Related Transnational Crime < http://www.baliprocess.net/>.
} 
Whilst the Bali Process does not of itself create legally binding obligations on Member States it has acted as an important mechanism to enable better action against human trafficking at the regional level. ${ }^{48}$

The efforts of Indonesia both domestically and internationally combine to demonstrate the importance of transnational cooperation to combat human trafficking. Whilst at a domestic level Indonesia has struggled to effectively address human trafficking due to factors including corruption and a lack of funding for task force, at the international level Indonesia has managed to cooperate as part of a broad regional approach. International approaches to human trafficking that combine the funding, intelligence and force of many countries have proven to be a method of combatting human trafficking.

\section{Terrorism - Indonesian And Asean} Responses

Since the turn of the century and the tragic terror attacks of $9 / 11$ and the

\footnotetext{
${ }^{48}$ Atmasasmita, above n 11, 679.

49 Jonathan Chow, 'ASEAN Counterterrorism Cooperation Since 9/11' (2005) 45 Asian Survey 302, 304.

${ }^{50}$ Ibid 303.
}

2002 Bali Bombings, terrorism has featured in the global spotlight as an issue requiring worldwide cooperation. Within South East Asia, terrorism has become an area of significant concern and has prompted regional cooperation so as to develop strategies to address the crime. ${ }^{49}$ Prior to the occurrence of $9 / 11$, terrorism was primarily treated as a domestic issue within Asian countries with little transnational cooperation as terrorist groups tended to be located within a single country. ${ }^{50}$

Indonesia's history of terrorism and counter-terrorism action provides a clear example of the problems associated with treating terrorist activities as a solely domestic problem. Until the start of the $21^{\text {st }}$ century terrorism was linked to separatist movements in several Indonesian provinces, ${ }^{51}$ however the governmental approach to these situations was authoritarian and used military force and anti-subversion legislation to crush uprisings. ${ }^{52}$ Prior to 9/11 Indonesia had not enacted specific anti-terrorism legislation nor had they become a signatory to or ratified the UN

\footnotetext{
${ }^{51}$ Ibid 305.

52 Kent Roach, The 9/11 Effect: Comparative Counter-Terrorism (Cambridge University Press, 2011) 143.
} 
Conventions $^{53}$ relating to terrorist funding and bombings. ${ }^{54}$ Indeed, in the years prior to the Bali Bombings, the Indonesian government appeared to be in denial regarding terrorism, with Vice President Hamzah Haz asserting that there were no terrorists in Indonesia. ${ }^{55}$ The failure of Indonesia to recognise the threat of terrorism and lack of international cooperation to stand against terrorist activities ultimately culminated in the 2002 Bali Bombings which acted as the impetus for great counterterrorism activity both domestically and through international cooperation.

The usefulness of bilateral arrangements in combatting terrorist threats has been demonstrated through a memorandum of understanding signed between Indonesia and Australia in the wake of the Bali Bombings. ${ }^{56}$ As almost

\footnotetext{
${ }^{53}$ See for example: International Convention for the Suppression of Terrorist Bombings, opened for signature 12 January 1998, 2149 UNTS 256 (entered into force 23 May 2001); International Convention for the Suppression of the Financing of Terrorism, opened for signature 10 January 2000, 2178 UNTS 197 (entered into force 10 April 2002); International Convention for the Suppression of Acts of Nuclear Terrorism, opened for signature 14 September 2005, 2445 UNTS 89 (entered into force 7 July 2007).

${ }^{54}$ Roach, above n 49, 145.

${ }^{55}$ Ibid 144.

${ }^{56}$ Memorandum of Understanding between the Government of the Republic of Indonesia and the
}

fifty percent of the victims of the Bali Bombings were Australian, Australia had a vested interest in ensuring that the perpetrators of the attack were brought to justice. ${ }^{57}$ The memorandum of understanding expressed the intent of both countries to enhance cooperation between defence, security and law enforcement agencies to combat terrorism. ${ }^{58}$ The framework provided by this agreement allowed Australian police to almost immediately respond following the Bali Bombings, coordinating a joint investigation which was ultimately responsible for the arrest of the alleged perpetrators. ${ }^{59}$ The undeniably effective efforts of Australian and Indonesian officials in the wake of the Bali Bombings was ultimately afforded through the presence of a memorandum of understanding and strong cooperative intent shared between

Government of Australia on Combatting International Terrorism, signed February 2002.

${ }^{57}$ Australian Federal Police, Submission No 62 to Joint Standing Committee on Foreign Affairs, Defence and Trade, Inquiry into Australia's Relations with Indonesia, November 2002, 927.

${ }^{58}$ Memorandum of Understanding between the Government of the Republic of Indonesia and the Government of Australia on Combatting International Terrorism, signed February 2002.

59 John McFarlane, 'Regional and International Cooperation in Tackling Transnational Crime, Terrorism and the Problems of Disrupted States' (2005) 12 Journal of Financial Crime 301, 305. 
the countries. This demonstrates the importance of transnational cooperation designed to cater for the needs of both nations.

Within the ASEAN nations as a whole following the terrorist attacks of 9/11 there became an increased awareness of, although not an immediately productive response to the threat of terrorism. ${ }^{60}$ ASEAN member states differed in their belief as to how collectively they should act to fight terrorism due to differences in domestic political stability and varying concerns as to the impact that involving other nations in counter-terrorism may have. ${ }^{61}$ Indonesia is a notable example of this, as their government appeared ambivalent regarding multilateral counterterrorism cooperation with the United States. The United States military action in the Middle East was seen by as an attack on Islam, not against terrorism by many Islamic groups within Indonesia. ${ }^{62}$ These groups were vocal in their denouncement of the United States and contributed to the initial Indonesian refusal to treat terrorism as a transnational issue. ${ }^{63}$ It

\footnotetext{
${ }^{60}$ Chow, above n 46, 302.

${ }^{61}$ Ibid 314.

${ }^{62}$ Chow, above n 45, 307.

63 Ibid.
}

was not until after the Bali Bombings that Indonesia and ASEAN as a whole began to take serious action at a regional level to address terrorism.

ASEAN has been an essential component of coordinating regional action to combat terrorism in South East Asia as evidenced by the arrest and conviction of numerous individuals involved in the Bali Bombings and other terrorist activities. One of the first arrests was of Abu Bakar Ba'aysir, the alleged spiritual leader of Jemaah Islamiyah, the terrorist organisation which claimed responsibility for the Bali Bombings. ${ }^{64}$ This was quickly followed by further arrests throughout Indonesia, Thailand and Singapore of individuals linked to the Bali Bombings and other terrorist activities. ${ }^{65}$ Many of these arrests were carried out following intelligence sharing between the three nations, ${ }^{66}$ demonstrating the benefits that multilateral cooperation conveys when combatting transnational crimes.

Greater consultation and cooperation between ASEAN members began to occur following the events of

\footnotetext{
${ }^{64}$ Ibid 315.

65 Ibid 317.

66 Ibid 318.
} 
9/11 due to the recognition that a multifaceted approach was necessary to combat terrorism. ${ }^{67}$ One of the first arrangements was a trilateral agreement between the Philippines, Indonesia and Malaysia, later joined by Cambodia and Thailand. This agreement committed the parties to share information including airline passenger lists, names of known criminals, fingerprint databases, as well as to strengthen border security between the countries. ${ }^{68}$ This agreement has proven useful but as the countries in South East Asia vary in their anti-terror legislation, greater harmonisation was necessary so that differences in legal systems did not impede in efforts to control terrorism. ${ }^{69}$

In recognition of the transnational capabilities of terrorism to compromise the entire South East Asian region, all ASEAN member countries adopted the ASEAN Convention on Counter Terrorism (ACCT) in 2007, which then came into force in $2011 .^{70}$ The ACCT was introduced with the intent to unite the ASEAN member

67 Abdul Razak Ahmad, 'The ASEAN Convention on Counter-Terrorism 2007' (2013) 14 Asia-Pacific Journal on Human Rights and the Law 93, 93.

${ }^{68}$ David Shambaugh and Michael Yahuda (eds), International Relations of Asia (Rowman \& Littlefield Publishers, 2008) 200. countries, with the substantive content of the convention based on the twelve international treaties developed by the UN that were already in existence. ${ }^{71}$ The ACCT has helped to provide the ASEAN region with a more effective and regimented legal framework, an important characteristic given the varying anti-terrorism laws that exist throughout the ASEAN countries. ${ }^{72}$

Due to the transnational nature of terrorism and its increased potential to affect many nations at once, it has been imperative for the nations of South East Asia to develop a coordinated overarching strategy to address terrorism. Bilateral arrangements, such as the memorandum of understanding and cooperation between Indonesia and Australia following the Bali Bombings have been important as those nations were most affected by the attacks. However, it is important for bilateral arrangements to be part of a greater regional response such as the ACCT so as to facilitate effective preventative and counter-active measures across all areas.

\footnotetext{
${ }^{69}$ Ahmad, above n 63, 96.

${ }^{70}$ Ibid 94.

${ }^{71}$ Ibid 104.

${ }^{72}$ Ibid 96.
} 
Piracy: The Malacca and Singapore Straits, Trilateral, Regional And Extra-Regional Cooperation

Piracy is one of the world's oldest crimes, and remains a transnational crime of significant concern globally and particularly South East Asia today. ${ }^{73}$ The Malacca and Singapore Straits (the Straits), located in the shared territorial waters of Indonesia, Malaysia and Singapore (the littoral states) are considered as two of the most important shipping straits in the world. They provide the shortest navigational route between the Indian Ocean and South China Sea and play host to around 60,000 vessels per year, of which between thirty and forty percent are oil tankers, essential to the supply of the energy needs to many countries. ${ }^{74}$ It is therefore imperative that vessels passing through the Straits are able to do so free from the threat of piracy.

Piracy within the Straits has risen since the early 1990s in accordance with wider economic and legal factors. ${ }^{75}$ According to annual reports from the

73 Rheny Wahyuni Pulungan, 'Enhancing Maritime Security in the Malacca Strait: Cooperation Against Piracy and Maritime Terrorism' (2010) 7 Indonesian Journal of International Law 300, 309.

${ }^{74}$ Ibid 301.

${ }^{75}$ Ibid 302.
International Maritime Bureau (IMB), instances of piracy steadily rose until from 1990 until 1998, before the effects of the 1997 Asian financial crisis drove instances of piracy to significantly higher levels until 2004. ${ }^{76}$ It was evident by this point to the littoral states that efforts to combat piracy in the Straits were failing, and that stronger regional cooperation was required to address piracy.

Prior to the formation of a trilateral agreement between the littoral states, there were significant difficulties with transnational cooperation to counteract piracy in the Straits. ${ }^{77}$ Due to the nature of the Straits, international law was ill-equipped to provide how acts of piracy should be dealt with. The United Nations Convention on the Law of the Sea (UNCLOS) defines piracy narrowly, limiting it to illegal acts of violence or detention committed on the high seas or outside the jurisdiction of any state. ${ }^{78}$ The narrowness of this definition would exclude it from covering many attacks in

\footnotetext{
76 Ibid.

${ }^{77}$ Ibid 303.

${ }^{78}$ United Nations Convention on the Law of the Sea, opened for signature 10 December 1982, 1833 UNTS 3 (entered into force 16 November 1994) art 101 ('UNCLOS').
} 
the Straits, which occur within the territorial waters of the littoral states.

Additionally, due to concerns of national sovereignty, the littoral states and extra-regional states lacked a coordinated plan of action to combat piracy within the Straits. National sovereignty, the right of a state to maintain absolute governance over aspects within its jurisdiction ${ }^{79}$ has been a concern of both Indonesia and Malaysia and a key factor in their consistent rejection of extra-regional offers to assist in patrolling the Straits. ${ }^{80}$

Furthermore, the complexities of pursuing a pirate vessel are compounded when they take place between states that share maritime borders. As provided by the UNCLOS, a coastal state is allowed to pursue a foreign vessel from within its own territorial waters into international waters, or to pursue a pirate ship whilst in international waters. ${ }^{81}$ However, both these rights cease once the pursued ship enters another state's territorial waters, ${ }^{82}$ effectively preventing arrest unless there

\footnotetext{
${ }^{79}$ Pulungan, above n 69, 303.

${ }^{80}$ Ibid 320.

${ }^{81}$ UNCLOS, arts 105, 111.

${ }^{82}$ Ibid arts 105, 111(3).

${ }^{83}$ Hersapta Mulyono, 'Yo Ho Ho and a Bucket of Cash the Need to Enchance [sic] Regional Effort to Combat Piracy and Armed Robbery
}

is coordination with the state whose territory the pursued ship has entered.

In recognition of the need for law enforcement cooperation to address the problems created by the gap in international law relating to piracy within the Straits, coordinated naval patrol arrangements between Indonesia and Singapore, and Indonesia and Malaysia have been carried out since the early 1990s. ${ }^{83}$ The success of these agreements prompted the establishment of the first trilateral maritime security arrangement between the littoral states, established in 2004 and known as the Malacca Straits Patrol Network. ${ }^{84}$ This arrangement established year-round patrols involving dedicated ships from each of the littoral states. ${ }^{85}$ Following the early success of these patrols, in 2005 Thailand became a member of the Patrol Network and the four countries began to conduct air patrols of the Malacca Strait as part of the 'Eyes in the Sky Program' ${ }^{86}$ It is clear that both of these patrols have had a positive impact on the

\footnotetext{
Against Ships in Southeast Asia' (2015) 12 Indonesian Journal of International Law 60, 80. 84 Shicun $\mathrm{Wu}$ and Keyuan Zou, Maritime Security in the South China Sea: Regional Implications and International Cooperation (Ashgate, 2009) 61.

${ }^{85}$ Mulyono, above n 79, 80.

${ }^{86}$ Pulungan, above n 69, 322.
} 
rates of piracy in the Straits; annual reports from the IMB demonstrate that instances of piracy remained low in the years following the introduction of the maritime and air patrols. ${ }^{87}$

Despite the success of the littoral states in combatting transnational piracy, there are areas in which improvements could be made to domestic legislation, policies and international agreements so as to further strengthen their ability to protect the Straits. First, the maritime patrols conducted by the littoral states are coordinated as opposed to joint patrols, meaning that there is no right for one state to pursue a pirate vessel into another state's territorial waters. ${ }^{88}$ This is in contrast to the Eyes in the Sky Program which allows aircraft to pursue a pirate vessel through another state's territory. ${ }^{89}$ The establishment of an agreement between the littoral states to allow joint patrols into areas in which piracy frequently occurs would allow the enforcement of jurisdiction over the pirates inside another state's territory. ${ }^{90}$ This would increase the capacity of the patrols to arrest and prosecute suspected

\footnotetext{
${ }^{87}$ Ibid 302.

${ }^{88}$ Ibid 324.

${ }^{89}$ Ibid 322.

${ }^{90}$ Ibid 324.
}

pirates and be beneficial to the control of piracy in the Straits.

Additionally, the establishment of a trilateral information and intelligence exchange agreement between the littoral states would allow greater coordination in relation to incidences of piracy. Such an agreement could mirror an arrangement between the Philippines, Indonesia and Malaysia which established a framework of areas in which the states would cooperate, how jurisdiction for transnational crimes would be determined, and how information would be communicated between the states. ${ }^{91}$ This would prove beneficial to the littoral states not only in the ability to better coordinate patrols to arrest suspected pirates, but also if issues of jurisdiction arose as to which state should have the capacity to prosecute each offender.

A further method of transnational cooperation that could be used to great effect by the littoral states in the Straits is the introduction of shiprider agreements. Shiprider agreements facilitate the placement of law

\footnotetext{
91 Agreement on Information exchange and Establishment of Communication Procedures, Indonesia-Malaysia-Philippines (signed and entered into force 7 May 2002).
} 
enforcement personnel from one state on board another state's vessel. Whilst on board, the shiprider has the authority to permit pirates to be chased into their state's territorial waters. ${ }^{92}$ This would address the current inability of the littoral states to engage in hot pursuit of pirate vessels and provide an additional advantage of being able to carry out investigations on behalf of their state in accordance with their national laws. ${ }^{93}$ Such agreements have been put in place between other states, ${ }^{94}$ and their usefulness has been lauded by the United Nations Security Council. ${ }^{95}$ Within the context of the Straits, the implementation of a trilateral shiprider agreement would further strengthen the ability of the littoral states to effectively combat transnational piracy.

As a whole, the efforts of the littoral states to address piracy within the Straits have been successful as evidenced by the decline in incidences of piracy since the introduction of a trilateral agreement between the nations. ${ }^{96}$ Due to the close-packed nature

\footnotetext{
${ }^{92}$ Mulyono, above n 79, 81.

93 Ibid.

${ }^{94}$ Agreement between the Government of The Republic of Trinidad and Tobago and the Government of the United States of America Concerning Maritime Counter-Drug Operations (signed and entered into force 4 March 1996).
}

of territorial jurisdictions within the Straits, trilateral cooperation in the form of coordinated border patrols is an effective way to manage the occurrence of piracy. However, greater trilateral coordination in the form of consistent legislation, permission to carry out hot pursuits of suspected pirates, greater information sharing and the introduction of shiprider agreements would almost certainly increase the ability to manage the transnational nature of piracy within the Straits.

\section{Illegal Wildlife Trafficking: Thailand, South East Asian and Asean Responses}

The illegal trafficking of wildlife is considered to be a transnational crime of serious concern to all nations, both in terms of the threat it poses to biodiversity through excessive hunting, and its deleterious impact on the social and economic growth potential of humans. ${ }^{97}$ The combined value of the illegal wildlife trade is estimated at US \$2.5 billion per year, ${ }^{98}$ of which $25 \%$ is

\footnotetext{
95 Mulyono, above n 79, 80.

${ }^{96}$ Pulungan, above n 69, 302.

${ }^{97}$ Transnational Organised Crime in East Asia and the Pacific, 77.

${ }^{98}$ Transnational Organised Crime in East Asia and the Pacific, 86.
} 
believed to derive from South East Asia. ${ }^{99}$ Wildlife may be illegally trafficked from one corner of the globe to the other, making this a transnational crime that requires strong legislation and enforcement domestically, as well as regional and worldwide cooperation.

The first global effort to combat the illegal trafficking of wildlife was established by the United Nations Convention on International Trade in Endangered Species of Wild Fauna and Flora (CITES), passed in $1973 .{ }^{100}$ CITES was established with the aim of ensuring that the international trade in wildlife would not threaten their survival, ${ }^{101}$ however its usefulness as a tool to combat wildlife trafficking is somewhat limited. Though the vast majority of states, and all countries in South East Asia are now a party to CITES, ${ }^{102}$ it lacks the force of law unless implemented into

\footnotetext{
99 Jolene Lin, ‘Tackling Southeast Asia’s Illegal Wildlife Trade' (2005) 9 Singapore Year Book of International Law 191, 201.

100 Convention on the International Trade in Endangered Species of Flora and Fauna, opened for signature 3 March 1973, 993 UNTS 244 (entered into force 1 July 1975).

${ }^{101}$ Ibid 245.

102181 of the 193 UN member states are now parties to CITES, with only Andorra, the Democratic People's Republic of Korea, the Federated States of Micronesia, Haiti, Kiribati, the Marshall Islands, Nauru, South Sudan, Timor-
}

domestic legislation and effectively enforced. ${ }^{103}$

Further, the necessity of domestic legislation for enforcement has additional weakness. In situations where states fail to enact legislation that adequately matches the standard set by CITES, or the penalties for contravention are weak, traffickers are able to exploit loopholes in laws and are not sufficiently deterred from engaging in the behaviour. ${ }^{104}$ This weakness is demonstrated by the trade in ivory within Thailand, where it remains legal to trade in domestic ivory. ${ }^{105}$ This loophole has been exploited to great effect by traffickers of African elephant ivory who are able to 'launder' illegally imported ivory so that it may be passed off as legal domestic ivory within Thailand. ${ }^{106}$

Global awareness of the lax efforts to curb ivory trafficking in Thailand led to a request by the

Leste, Tonga, Turkmenistan, and Tuvalu abstaining.

${ }^{103}$ Lin, above n 95, 192.

104 Kristy Phillips, 'Earth Can’t Bear it: How International Law Fails to Protect the Endangered Malayan Sun Bear' (2004) 28 Suffolk Transnational law Review 113, 130.

${ }_{105}$ Ranee Khooshie Lal Panjabi, 'For Trinkets, Tonics, and Terrorism: International Wildlife Poaching in the Twenty-First Century' (2014) 43 Georgia Journal of International and Comparative Law 1, 37.

${ }^{106}$ Ibid 38. 
Conference of Parties to CITES for Thailand to develop a national ivory action plan (NIAP) in 2013, ${ }^{107}$ followed by a revision of that plan in $2014 .{ }^{108}$ Following these recommendations, Thailand has been implementing its revised NIAP as of October $2014^{109}$ and has introduced new ${ }^{110}$ and amended legislation ${ }^{111}$ to improve control of both the legal domestic and illegal international ivory trade. In addition, stronger law enforcement, monitoring of the domestic trade, increased customs inspections and the sharing of intelligence and information both domestically and internationally has resulted in over 15 cases of arrests and the confiscation of at least 13 tonnes of ivory since October $2014 .{ }^{112}$ The recent success of Thailand in addressing the illegal trafficking of ivory can be seen as a direct result of their commitment to work as part of a global network to

107 National Ivory Action Plans, 64 ${ }^{\text {th }}$ meeting of the Standing Committee of CITES, SC64 Doc 2 (14 March 2013) $<$ https://cites.org/sites/default/files/eng/com/sc/6 4/E-SC64-02.pdf>.

108 Interpretation and Implementation of the Convention - Species Trade and Conservation: Elephants, $65^{\text {th }}$ meeting of the Standing Committee of CITES, SC65 Com 7 (11 July 2014) <https://cites.org/sites/default/files/ eng/com/sc/65/com/E-SC65-Com-07.pdf>. 109 Sommal Kittayakul, Progress Report on the Implementation of Revised Thailand's National combat the transnational illegal wildlife trade.

However, the usefulness of a state acting alone to increase law enforcement controls is also limited as this may lead to traffickers simply redirecting their efforts into countries with weaker control mechanisms. ${ }^{113}$ In effect this means that the success of combatting illegal wildlife trafficking is dependent on how all source, transit and destination countries of illegal wildlife cooperate in the areas of legislation, policy, information sharing and enforcement. Evidence of the effectiveness of multinational enforcement cooperation to combat wildlife trafficking is provided by a 2014 operation in Africa, referred to as Operation Cobra II which involved law enforcement operatives from 28 source, transit and destination countries across the world. ${ }^{114}$ Cooperation between

Ivory Action Plan for SC66, $66^{\text {th }}$ meeting of the Standing Committee of CITES, SC66 Doc 29 (15 September 2015) annex 8 ('Thailand National Ivory Action Plan').

110 Elephant Ivory Act B.E. 2558 (2015)

(Thailand).

111 Wild Animal Reservation and Protection Act (No 3) B.E. 2557 (2014) (Thailand); Beast of Burden Act B.E. 2482 (1939) (Thailand).

112 Thailand National Ivory Action Plan, 5.

${ }^{113}$ Lin, above n 95, 202.

${ }^{114}$ Panjabi, above n 100, 77. 
police, customs and wildlife officials involving information sharing and coordinated operations resulted in the arrest of more than 400 individuals and 350 illegal wildlife seizures. ${ }^{115}$ Such success provides support for the necessity of international cooperation between all countries that have an interest in preventing wildlife trafficking.

In recognition of the importance of regional action in combatting illegal wildlife trafficking, a combined South East Asian response has been the focus of ASEAN members since 2004. ${ }^{116}$ The ASEAN Statement on CITES outlined important areas of cooperation and pledged to establish a Regional Action Plan to achieve the objects of the Statement. ${ }^{117}$ This pledge was realised with the establishment of the ASEAN Wildlife Enforcement Network

${ }^{115}$ Operation Cobra II, 'African, Asian and North American Law Enforcement Officers Team up to Apprehend Wildlife Criminals’ (Press Release, 10 February 2014) 1 $<$ https://cites.org/sites/default/files/eng/news/su ndry/ 2014/operation_cobra_ii_pr.pdf $>$.

${ }^{116}$ ASEAN Statement on CITES, $13^{\text {th }}$ meeting of the Conference of the Parties to CITES (11 October 2004)

$<$ http://www.asean.org/?static_post=aseanstatement-on-cites $>$.

${ }^{117}$ Lin, above n 95, 196.

118 Ibid 204.

119 ASEAN Regional Action Plan on Trade in CITES Wild Fauna and Flora, 2011-2015,
(ASEAN-WEN) in 2005, and marks the first time that all South East Asian nations have entered into cooperative efforts to curb the transnational trafficking of wildlife. ${ }^{118}$ ASEAN-WEN promotes the establishment of uniform legislation and policies, the strengthening of international law enforcement collaborations, and increased awareness of the legality of the trade in wildlife. ${ }^{119}$ Together with wildlife enforcement networks that have been established in all ASEAN countries, Asia's Regional Response to Endangered Species Trafficking (ARREST) Program, and TRAFFIC South East Asia, ${ }^{120}$ ASEAN-WEN has had great success, as demonstrated by the number of law enforcement actions reported in their annual updates. ${ }^{121}$

The actions of both Thailand and ASEAN as a whole indicate that the

special workshop of the ASEAN Experts Group on CITES (27 May 2011).

120 ASEAN Wildlife Enforcement Network, What is ASEAN-WEN? (2015) $<$ http://www.asean-wen.org/ index.php/aboutus/what-is-asean-wen>.

121 ASEAN Wildlife Enforcement Network, Action Update for the Year 2012 Law Enforcement Actions in Southeast Asia to Protect Threatened Flora and Fauna (2012) < http://www.asean-wen.org/index.php/reportspublications/file/53-asean-wen-action-updatesummary-2012>. There were 218 wildlife enforcement actions in 2011 with over 2 million live animals, 8000 dead animals and 23 metric tons of wildlife recovered. 
trafficking of wildlife can only be effectively combatted through domestic efforts combined with a strong regional commitment. The progress of Thailand in implementing its NIAP to combat the illegal trade in ivory emphasises that domestic action is essential to address transnational crime. However, the cooperation of nations is essential when confronted with a transnational crime as fluid as the illegal trafficking of wildlife.

\section{CONCLUSION}

The growing phenomenon of transnational organised crime is one which affects all nations, but has the potential for its greatest impact when efforts to address it are not coordinated across national boundaries. As demonstrated through the above analysis of wildlife trafficking, human trafficking, piracy and terrorism, the methods used to combat transnational organised crime must not only be coordinated on an international level, but also tailored to the unique qualities of the specific crime. This is because each crime has its impact at different points within individual countries and affects different countries in varying ways. Maritime piracy tends to affect countries with shared national borders as pirates move seamlessly across territorial boundaries, meaning that international cooperation must take this into account to be successful. Other crimes such as wildlife or human trafficking have their impact over a wider range of countries, meaning that strategies such as uniformly strong legislation, information and intelligence sharing may be more effective in combatting transnational organised crime. For all transnational crimes, what is imperative is that nations do not act alone, and instead cooperate through employing methods tailored to the crime in question.

\section{REFERENCES}

\section{A - Articles/Books/Reports}

Ahmad, Abdul Razak, 'The ASEAN Convention on CounterTerrorism 2007' (2013) 14 AsiaPacific Journal on Human Rights and the Law 93

Atmasasmita, Romli, 'International Cooperation on Combating Human Trafficking Especially Women and Children: A View from Indonesia', (2004) 1 Indonesian Journal of International Law 673

$\begin{array}{rr}\text { Chow, Jonathan } & \text { 'ASEAN } \\ \text { Counterterrorism } & \text { Cooperation }\end{array}$


Since 9/11' (2005) 45 Asian Survey 302

Hakem, Jeremy, Transnational Crime in the Developing World (Global Financial Integrity, 2011)

King, Lindsey, 'International Law and Human Trafficking’ (2009) Human Rights \& Human Welfare 88 , 90 $<$ http://www.du.edu/korbel/hrhw /researchdigest/trafficking/Traffi cking.pdf>

Kittayakul, Sommal, Progress Report on the Implementation of Revised Thailand's National Ivory Action Plan for SC66, $66^{\text {th }}$ meeting of the Standing Committee of CITES, SC66 Doc $29 \quad$ (15 September 2015) annex 8

Kusumaningrum, Adi, 'The ASEAN Political-Security Community: ASEAN Security Cooperation on Combatting Transnational Crimes’ (2013) Indonesian Journal of International Law 89 Lin, Jolene, 'Tackling South East Asia's Illegal Wildlife Trade' (2005) 9 Singapore Year Book of International Law 191

McFarlane, John, 'Regional and International Cooperation in Tackling Transnational Crime,
Terrorism and the Problems of Disrupted States' (2005) 12 Journal of Financial Crime 301 Mulyono, Hersapta, 'Yo Ho Ho and a Bucket of Cash the Need to Enchance [sic] Regional Effort to Combat Piracy and Armed Robbery Against Ships in South East Asia' (2015) 12 Indonesian Journal of International Law 60 Mustofa, Muhammad, 'Bilateral Cooperation Between Indonesia and Malaysia in Combating Transnational Crime' (2008) 5 Indonesian Journal of International Law 525

Panjabi, Ranee Khooshie Lal, 'For Trinkets, Tonics, and Terrorism: International Wildlife Poaching in the Twenty-First Century' (2014) 43 Georgia Journal of International and Comparative Law 1

Phillips, Kristy, 'Earth Can’t Bear it: How International Law Fails to Protect the Endangered Malayan Sun Bear' (2004) 28 Suffolk Transnational law Review 113 Pulungan, Rheny Wahyuni, 'Enhancing Maritime Security in the Malacca Strait: Cooperation Against Piracy and Maritime Terrorism’ 
Brawijaya Law Journal V.3 n.2 Contemporary Indigeneous and Constitutional Issues

(2010) 7 Indonesian Journal of International Law 300

Roach, Kent, The 9/11 Effect: Comparative Counter-Terrorism (Cambridge University Press, 2011)

Shambaugh, David and Michael Yahuda (eds), International Relations of Asia (Rowman \& Littlefield Publishers, 2008)

Sukma, Rizal, 'The Securitization of Human Trafficking in Indonesia’ (Working Paper, S. Rajaratnam School of International Studies, Singapore, 3 July 2008

United Nations Children’s Fund, ‘Every Child's Birth Right Inequities and Trends in Birth Registration' (UNICEF, December 2013)

United Nations Office on Drugs and Crime, Estimating Illicit Financial Flows Resulting from Drug Trafficking and other Transnational Organized Crimes, (October 2011)

United Nations Office on Drugs and Crime, Global Report on Trafficking in Persons, (February 2009)

United Nations Office on Drugs and Crime, Global Report on Trafficking in Persons, (2014)
United Nations Office on Drugs and Crime, Transnational Organised Crime in East Asia and the Pacific - A Threat Assessment, (April 2013)

United Nations Office on Drugs and Crime, UNODC Country Programme for Indonesia, 20122015, (2012)

U.S. Department of State, Trafficking in Persons Report (2001)

U.S. Department of State, Trafficking in Persons Report (2002)

U.S. Department of State, Trafficking in Persons Report (2003)

U.S. Department of State, Trafficking in Persons Report (2010)

U.S. Department of State, Trafficking in Persons Report (2011)

Wang, Peng and Jingyi Wang, 'Transnational Crime: Its Containment through International Cooperation’ (2009) 5 Asian Social Science 25

Wesley, Michael, 'Transnational Crime and Security Threats in Asia' (Report, Australian Agency for International Development, December 2007

Wisnumurti, Nugroho, 'Maritime Security Issues in South East Asia: An Indonesian Perspective’ 
Brawijaya Law Journal V.3 n.2 Contemporary Indigeneous and Constitutional Issues

(2009) 6 Indonesian Journal of International Law 333

Wu, Shicun and Keyuan Zou, Maritime

Security in the South China Sea:

Regional Implications and

International Cooperation

(Ashgate, 2009)

$\underline{B}$-Legislation

Beast of Burden Act B.E. 2482 (1939)

(Thailand)

Elephant Ivory Act B.E. 2558 (2015)

(Thailand)

Law of the Republic of Indonesia

Number 21 2007, Law on The

Eradication of the Criminal Act of

Trafficking in Persons

Wild Animal Reservation and Protection

Act (No 3) B.E. 2557 (2014) (Thailand)

$\underline{\mathrm{C}-\text { Treaties }}$

Agreement between the Government of The Republic of Trinidad and Tobago and the Government of the United States of America Concerning Maritime CounterDrug Operations (signed and entered into force 4 March 1996)

Agreement on Information exchange and

Establishment of Communication

Procedures, Indonesia-

Malaysia-Philippines (signed and entered into force 7 May 2002)

Convention on the International Trade in Endangered Species of Flora and Fauna, opened for signature 3 March 1973, 993 UNTS 244 (entered into force 1 July 1975) International Convention for the Suppression of Acts of Nuclear Terrorism, opened for signature 14 September 2005, 2445 UNTS 89 (entered into force 7 July 2007)

International Convention for the Suppression of Terrorist Bombings, opened for signature 12 January 1998, 2149 UNTS 256 (entered into force 23 May 2001)

International Convention for the Suppression of the Financing of Terrorism, opened for signature 10 January 2000, 2178 UNTS 197 (entered into force 10 April 2002)

Memorandum of Understanding between Government of the Republic of Indonesia and the Government of Malaysia on the Recruitment and Placement of Indonesian Domestic Workers, signed 13 May 2006 
Brawijaya Law Journal V.3 n.2 Contemporary Indigeneous and Constitutional Issues

Memorandum of Understanding between the Government of the Republic of Indonesia and the Government of Australia on Combatting International Terrorism, signed February 2002

United Nations Convention against Transnational Organised Crime, GA Res 55/25, UN GAUR, 55 $5^{\text {th }}$ sess, $62^{\text {nd }}$ plen mtg, Agenda Item 105, Supp No 49, UN Doc A/RES/55/25 (15 November 2000)

United Nations Convention against Transnational Organised Crime, GA Res 55/25, UN GAUR, 55 ${ }^{\text {th }}$ sess, $62^{\text {nd }}$ plen mtg, Agenda Item 105, Supp No 49, UN Doc A/RES/55/25 (15 November 2000) annex II

United Nations Convention on the Law of the Sea, opened for signature 10 December 1982, 1833 UNTS 3 (entered into force 16 November 1994)

Vienna Convention on the Law of Treaties, opened for signature 23 May 1969, 1115 UNTS 331 (entered into force 27 January 1980)

D-Other
About the Bali Process, The Bali Process on People Smuggling, Trafficking in Persons and Related Transnational Crime < http://www.baliprocess.net/> ASEAN Regional Action Plan on Trade in CITES Wild Fauna and Flora, 2011-2015, special workshop of the ASEAN Experts Group on CITES (27 May 2011)

ASEAN Statement on CITES, $13^{\text {th }}$ meeting of the Conference of the Parties to CITES (11 October 2004)

$<$ http://www.asean.org/?static_p ost=asean-statement-on-cites $>$

ASEAN Wildlife Enforcement Network, Action Update for the Year 2012 Law Enforcement Actions in South East Asia to Protect Threatened Flora and Fauna (2012) > http://www.aseanwen.org/index.php/reportspublications/file/53-asean-wenaction-update-summary-2012>

ASEAN Wildlife Enforcement Network, What is ASEAN-WEN? (2015) $<$ http://www.asean-wen.org/ index.php/about-us/what-isasean-wen>

Australian Federal Police, Submission No 62 to Joint Standing 
Committee on Foreign Affairs, Defence and Trade, Inquiry into Australia's Relations with Indonesia, November 2002

Betz, Diana, 'Human Trafficking in South East Asia: Causes and Policy Implications (Master's Thesis, Naval Postgraduate School, Monterey, California, 2009) 64

Interpretation and Implementation of the Convention - Species Trade and Conservation: Elephants, $65^{\text {th }}$ meeting of the Standing Committee of CITES, SC65 Com $7 \quad$ (11 July 2014) $<$ https://cites.org/sites/default/fil es/ eng/com/sc/65/com/E-SC65Com-07.pdf>

National Ivory Action Plans, $64^{\text {th }}$ meeting of the Standing Committee of CITES, SC64 Doc 2 (14 March 2013) https://cites.org/sites/default/file s/eng/com/sc/64/E-SC64-02.pdf Operation Cobra II, 'African, Asian and North American Law
Enforcement Officers Team up to Apprehend Wildlife Criminals' (Press Release, 10 February 2014) $<$ https://cites.org/sites/default/fil es/ eng/news/sundry/ 2014/operation_cobra_ii_pr.pdf

$>$

United Arab Emirates National Committee to Combat Human Trafficking, UAE, Indonesia to Sign $\mathrm{MoU}$ on Anti-Human Trafficking (13 September 2015) $<$ http://www.nccht.gov.ae/ default.aspx?

PageId=66\&EventID=2>

Zeldin, Wendy, Indonesia; Taiwan: Agreement to Combat Human Trafficking (October 5 2012) Library of Congress $<$ http://www.loc.gov/law/foreign -news/article/indonesia-taiwanagreement-to-combat-humantrafficking/> 